\title{
KILKA UWAG O LOGICE PRZEKONAŃ RELIGIJNYCH*
}

W niniejszym artykule podjęta zostanie próba zastosowania narzędzi wypracowanych $\mathrm{w}$ logice do analizy pojęcia przekonania religijnego. Najpierw pojęcie przekonania religijnego zostanie porównane z pojęciem przekonania charakteryzowanym w logice oraz z przekonaniami naukowymi. Następnie będzie przedstawiona logiczna analiza warunków racjonalności przekonań religijnych i w końcu zostanie podjęta próba odniesienia „klasycznych” określeń wiary sformułowanych przez św. Tomasza z Akwinu do języka logiki.

Samo pojęcie przekonania religijnego doczekało się wielu analiz filozoficznych, lecz logicznych analiz jego specyfiki można znaleźć niewiele. Prekursorem w tym względzie jest Józef M. Bocheński i jego pochodząca z 1965 r. The logic of religion (wydanie polskie: Logika religii $=$ BOCHEŃSKI 1990). Na gruncie polskim sporo interesujących uwag wnieśli także Jan Woleński w pracy Granice niewiary (WOLEŃSKI 2004) oraz Jacek J. Jadacki (JADACKI 2003). Wspomniany J.M. Bocheński w innej swojej pracy (BOCHEŃSKI 1994), zamieszczonej w zbiorze pod red. Paula Weingartnera Scientific and religious belief (WEINGARTNER 1994), a także w dyskusji wokół innych zamieszczonych $\mathrm{w}$ tej książce artykułów znacznie zmodyfikował swoje stanowisko. Rozważania niniejsze prowadzone będą w kontekście ustaleń poczynionych przez św. Tomasza z Akwinu (w szczególności w kwestiach STh II-II, 1-16, dotyczących wiary).

Dr hab. Marek LechniaK, Prof. KUL - Katolicki Uniwersytet Lubelski Jana Pawła II, Wydział Filozofii, Instytut Filozofii, Katedra Logiki; adres do korespondencji: Al. Racławickie 14, 20 950 Lublin; e-mail: marek.lechniak@kul.pl; ORCID: https://orcid.org/0000-0002-0768-7963.

* Tekst niniejszy stanowi poszerzoną wersję referatu wygłoszonego na konferencji „Bóg a przekonania religijne", Lublin, 25 listopada $2018 \mathrm{r}$.

Artykuł dofinansowany w ramach programu Ministra Nauki i Szkolnictwa Wyższego pod nazwą ,Regionalna Inicjatywa Doskonałości” w latach 2019-2022, nr projektu 028/RID/2018/19, kwota finansowania całości programu: 11742500 PLN. 


\section{PRZEKONANIE A WIARA (PRZEKONANIE RELIGIJNE)}

Termin „przekonanie” używany jest zwykle na określenie stanu (dyspozycji) podmiotu poznającego lub też na określenie wytworu (przedmiotu, treści?) tego stanu, czyli zdania uznawanego przez jakiś podmiot (grupę podmiotów) za prawdziwe. Tego typu dwoistość prowadzi często do pewnego zamieszania terminologicznego. Dla ścisłości warto chyba stosować dookreślenia: stan (dyspozycja do) żywienia przekonania albo „bycie $x$-a przekonanym, że” (,x jest przekonany, że”) oraz „treść przekonania”.

Przez przekonanie można rozumieć zapoczątkowany przez akt (moment) uznawania stan umysłowy podmiotu, który to stan dysponuje podmiot do aktu myślenia lub zachowania się i przejawia się przez ten akt ${ }^{1}$. Określenie to jest wyrazem tzw. stanowej koncepcji przekonania. Przekonanie jest charakteryzowane przez kilka ważnych pojęć z nim sprzężonych, a mianowicie:

a) Przedmiot i treść przekonania - jest nim rzecz (obiekt) konkretna lub abstrakcyjna, o określonych cechach lub pozostająca $\mathrm{w}$ pewnych relacjach (ta koncepcja przyjmowana jest $\mathrm{w}$ tradycji Brentanistycznej) albo sąd (w sensie logicznym, proposition - koncepcja niemal powszechna w tradycji anglosaskiej); stąd przekonania zalicza się do tzw. postaw (nastawień) propozycjonalnych (WOLEŃSKi 2004, 44). Ten ostatni pogląd ten zdaje się opierać na niedostatecznym rozróżnieniu przedmiotu przekonania (do czego się przekonania odnosi) od treści przekonań (WOLEŃSKi 2004, 45).

b) Podmiot przekonania, który winien posiadać m.in. zdolność sądzenia (wydawania sądów), czyli uznawania rzeczywistości obiektów poza podmiotem, intencjonalny kontakt z rzeczywistością, zdolność do zapamiętywania i przechowywania w pamięci treści sądów, zdolność do przypominania sobie, zdolność do wyprowadzania wniosków i w końcu zdolność do działania zgodnie z przekonaniami, uczenia się, komunikowania przekonań oraz zdolność do posługiwania się językiem.

c) Nabywanie przekonań — większość przekonań stanowią przekonania epistemiczne (czyli takie, których przedmiotem jest jakiś obiekt, stan świata), nabywane w sposób spontaniczny (w rezultacie spostrzeżeń czy informacji pochodzących z wiarogodnego źródła). Czasem jednak przekonania mogą

\footnotetext{
${ }^{1}$ Określenie to ma korzenie w Twardowskiego rozróżnieniu wytworu, aktu i dyspozycji do aktu — szersze przedstawienie stanowisk autorów szeroko pojętej szkoły lwowsko-warszawskiej można znaleźć w LECHNIAK 2011, 27-56; por. także LECHNIAK 2018. W podobnym duchu określa przekonanie Jan Woleński: „treściowo określony stan mentalny, ujawniający się przez stosowne zachowania" (WOLEŃSKI 2004, 40).
} 
być rezultatem szeregu aktów akceptacji (mają one wtedy charakter ontycznie wtórny względem tych pierwszych).

d) Zmiana przekonania ( $w$ tym rezygnacja podmiotu z żywionych przekonań), która może być:

(i) zmianą „substancjalną” (powstawanie albo ginięcie przekonania), w odmianach:

- nabycie (nowego) przekonania, czyli przejście od braku przekonania do posiadania przekonania;

- usunięcie przekonania, czyli przejście od żywienia przekonania do jego braku;

- rewizja, czyli zastąpienie przekonania przez jego negację ${ }^{2}$.

(ii) zmianą typu ,ruch”, czyli modyfikacją poszczególnych momentów przekonania - jego treści, siły, zachowaniowego korelatu czy językowego sformułowania (korelatu) treści przekonania. Od strony logicznej posiadanie przekonania zwykle opisuje się za pomocą frazy czasownikowej „, $x$ jest przekonany, że $p ”$, która jest reprezentowana przez funktor nieekstensjonalny odpowiadający funktorowi konieczności, czyli postaci $F_{x} p$ (LeChNiaK 2011). To, jakie konkretnie własności ma ten funktor, jest wyznaczone przez rządzące nim aksjomaty (w wersji syntaktycznej) lub też warunki spełniania w modelu (w wersji semantycznej) ${ }^{3}$.

Jaka jest relacja przekonań religijnych do przekonań tak opisanych? Zagadnienie to podejmuje Paul Weingartner w pracy Similarities and differences between scientific and religious belief (WEINGARTNER 1994a), gdzie odróżnia tzw. G-przekonanie oraz B-przekonania:

a) G-przekonanie (od niem. Glauben - wiara) jest charakteryzowane za pomocą tezy: jeżeli ktoś wierzy w coś, to nie wie on tego, i odwrotnie jeśli ktoś coś wie, to nie wierzy w to. Tak pojęte wiara i wiedza wykluczają się, np. przed odkryciem dowodu niezależności hipotezy continuum od aksjomatów teorii mnogości von Neumann wierzył w tę niezależność, ale tego nie wiedział. G-przekonanie charakteryzują zatem następujące formuły: $G_{a} p \rightarrow \neg K_{a} p$ albo $K_{a} p \rightarrow \neg G_{a} p$. Wiara i wiedza są pojęciami o zakresach przeciwnych $\neg\left(G_{a} p \wedge K_{a} p\right)$.

\footnotetext{
${ }^{2}$ Te trzy rodzaje zmiany, zwane odpowiednio ekspansją, kontrakcją i rewizją, są bazowymi rodzajami zmiany przekonaniowej wyróżnionymi w opartym na założeniu koherencyjnym modelu AGM zmiany przekonaniowej (por. GÄRDENFORS 1988; LECHNIAK 2011).

${ }^{3}$ To, w jaki sposób określać owe warunki od strony epistemologicznej, pokazuje np. W. Lenzen (LENZEN 1978).
} 
b) B-przekonanie wyraża się tezą ,jeżeli ktoś coś wie, to i wierzy w to, i odwrotnie - jeśli ktoś nie wierzy w coś, nie wie tego” — „wierzyć (w sensie B), że $p$ jest faktem, znaczy po prostu myśleć, że $p$ jest prawdziwe, utrzymywać, że $p$ jest prawdziwe czy mocno zakładać, że $p$ jest prawdziwe. Jeśli ktoś wie, że chromosomy podwajają się, on B-wierzy też, że tak jest" (WEINGARTNER 1994a, 109). Te dwa pojęcia przekonania mają, według Weingartnera, m.in. następujące własności formalne $e^{4}$ :

1) relacja G-przekonań i B-przekonań do wiedzy: $K_{a} p \rightarrow B_{a} p$ oraz $G_{a} p \rightarrow B_{a} p$, czyli zarówno wiedza, jak i wiara mają składową przekonaniową;

2) odpowiednik aksjomatu D dla obu rodzajów przekonań, czyli, inaczej mówiąc, teza o niesprzeczności zarówno G, jak i B-przekonań, czyli $G_{a} p \rightarrow \neg G_{a} \neg p \quad B_{a} p \rightarrow \neg B_{a} \neg p$; poza tym Weingartner podaje formuly $\operatorname{Con}\left(G_{a} p \wedge p\right) \rightarrow \operatorname{Con}_{a} p$ oraz $\operatorname{Con}\left(p \rightarrow \operatorname{Con} G_{a} p\right)$, ale nie odwrotnie $\left(\operatorname{Con}\left(G_{a} p \rightarrow \operatorname{Con}(p)\right)\right)$, mające wyrażać kryteria niesprzeczności (WeINGARTNER 1994a, 115$)^{5}$. Z tymi kryteriami jest związana również teza wyrażająca fakt, że „Każdy ma rację dla swojej wiary (to, w co wierzy, nie jest niemożliwe), czyli $G_{a} p \rightarrow B_{a} \operatorname{Con}(p)$ albo inaczej $G_{a} p \rightarrow B_{a} \Delta p$ ( $\Delta$ — „Jest możliwe, że”) — jest to wyraz racjonalności wiary ${ }^{6}$.

3) Twierdzenia „urealniające” pojęcie wiary, czyli typowe „osłabiacze”, takie jak:

- Wszyscy wierzący wierzą w coś, co jest prawdziwe, albo nikt nie wierzy wyłącznie $\mathrm{w}$ to, co jest fałszywe, czyli: $\forall x \exists p\left(G_{x} p \wedge p\right)$ (i odpowiednio: $\neg \exists x \forall p\left(G_{x} p \rightarrow \neg p\right)$;

- Każdy dopuszcza wiarę w przynajmniej jeden fałsz: $\forall x \exists p\left(G_{a} p \wedge \neg p\right)$;

- Żadne credo nie jest zupełne; ,przez credo wierzącego rozumiem system sądów (oraz być może dodatkowo norm lub reguł), które charakteryzują poszczególną religię (lub dyscyplinę naukową), które są przedmiotem wiary kogoś, kto jest zaliczany do członków tej społeczności

\footnotetext{
${ }^{4} \mathrm{Na}$ gruncie logik epistemicznych czy wskazywanych wyżej rozważań epistemologii formalnej pojęcie przekonania (mocniejsze, jako conviction, pewność) charakteryzuje się zwykle za pomocą aksjomatów systemu KD45. Tak charakteryzowane przekonanie ma jednak cechę logicznej wszechwiedzy, której Weingartner chce uniknąć.

${ }^{5}$ Te formuły nie do końca można uznać za wartościowe; raczej powinno być tu, że zbiory zdań będących treścią wiary są niesprzeczne albo zbiory „postaw” (stanów) wyrażanych formułami $G_{x} p$ są niesprzeczne, natomiast trudno stwierdzać niesprzeczność treści postawy (stanu) z postawą (stanem). Ogólnie trzeba jednak się zgodzić z Weingartnerem, że zbiór przekonań (czy to religijnych, czy jakichś innych) winien być niesprzeczny (jest to jedno z kryteriów racjonalności logicznej).

${ }^{6}$ Przeciwny do tezy credo quia absurdum (błędnie) przypisywanej Tertulianowi.
} 
religijnej lub badaczy danej dyscypliny naukowej. Nazwę takie credo zupełnym ze względu na specjalne pole (z którym wiara jest powiązana), jeśli wszystkie sądy prawdziwe (i wszystkie ważne reguły i normy) tego pola są zawarte w credo lub z niego logicznie wyprowadzalne" (WeINGARTNER 1994a, 118); wszechwiara (odpowiednik wszechwiedzy) byłaby wyrażalna za pomocą formuły $\forall p\left(p \in F \rightarrow G_{x} p\right)$ (gdzie $F$ oznacza zbiór sądów będących polem wiary), negacja wszechwiary przyjmie zatem formę $F \wedge \neg G_{x} p$ ).

Weingartner podaje także listę podobieństw oraz różnic między wiarą w sensie religijnym i przekonaniami naukowymi. Lista dalszych (poza wymienionymi wyżej) podobieństw obejmuje następujące punkty:

- Treści przekonań religijnych i przekonań naukowych mają charakter propozycjonalny i normatywny (podmiot wierzy w ważność (obowiązywalność) norm). (WEINGARTNER 1994a, 107).

- Przekonania są niesprzeczne i pozbawione dedukcyjnej (i logicznej) wszechwiedzy, za to spełniają „,proste i ważne zasady logiczne” takie jak modus ponens, modus tollens, sylogizm warunkowy, sylogizm dysjunkcyjny (opuszczanie alternatywy), dictum de omni $\left(G_{a} \forall x F x \rightarrow G_{a} F b\right)$, ekstensjonalność (?) w postaci $\left[G_{a}(b=c) \wedge G_{a} F b\right] \rightarrow G_{a} F c$ czy rozkładanie funktora $\mathrm{G}$ na człony koniunkcji (implikacji);

- Przeciwieństwo pojęć wiedzy i wiary (w sensie G-wiary);

- To, w co wierzymy, ma konsekwencje potwierdzone. Ta teza, jak zauważa Weingartner, dla przekonań naukowych zdaje się być trywialna. „[Osoby] posiadające przekonania religijne mają poglądy, w których interpretują piękno i porządek w świecie jako przykłady potwierdzające ich wiarę we wszechmocnego i wszechwiedzącego Stwórcę. Lub też mogą zobaczyć przykłady potwierdzające doktryny etyczne w Biblii, gdy obserwują życie rodzinne czy życie społeczne" (WeIngARTNER 1994a, 121).

\footnotetext{
${ }^{7}$ Są to typowe minimalne warunki logiczności przekonań. Samo określenie in concreto takich minimalnych warunków logiczności jest jednak sprawą prawie beznadziejną (LECHNIAK 2011, 127141). Oczywiście wśród zasad preferowanych przez Weingartnera brak jest reguły Gödla, co czyni, że te wymagania konstytuują jakiś system słabszy od logiki normalnej. W literaturze znane są niekończące się dyskusje dotyczące osłabienia postulatu logicznej wszechwiedzy (wszechprzekonań); krótki przegląd stanowisk można znaleźć w LECHNIAK 2011, 231-247. Podobną do Weingartnerowskiej strategię ograniczania postulowanych przez system zdolności logicznych podmiotu żywiącego przekonania stosuje J.J. Jadacki (JADACKI 2003); strategia ograniczania zdolności podmiotu prowadzi do opisu może i zbliżonego do adekwatnego, za to pozbawionego „mocy dedukcyjnej”; w takim systemie ciężko jest wyprowadzić jakieś ciekawsze logicznie twierdzenia.
} 
Z kolei różnice między przekonaniami religijnymi a naukowymi można zestawić za Weingartnerem w sposób następujący:

- Pierwsza z różnic dotyczy tego, co przedłożone jest do wierzenia. Dla przekonań religijnych jest to „tekst założycielski” (Biblia, Koran) lub też ustna tradycja rytualna, często streszczane w postaci Credo. Inaczej jest w wypadku przekonań naukowych. To, co przedkładane do wierzenia, jest „proponowane, rozważane, wymyślane, konstruowane w trakcie rozwoju danej dyscypliny". Nawet jeśli dopuścimy istnienie swego rodzaju credo w danej dziedzinie nauki (WEINGARTNER 1994a, 122), to jednak, w przeciwieństwie do religii, ulega ono znacznemu rozwojowi;

- W przypadku przekonań religijnych towarzyszy im przekonanie, że to, w co wierzymy, nie może być fałszywe; w wypadku przekonań naukowych, zwykle dopuszcza się możliwość ich fałszywości, czyli $G_{a}^{R} p \rightarrow B_{a} \neg \Delta\left(G_{a}^{R} p \wedge \neg p\right)$.

- Przekonania religijne powiązane są z pragnieniem szczęścia, podczas gdy nie ma takiego powiązania w przypadku przekonań naukowych. „To szczególne przywiązanie przekonań religijnych do transcendentnego stanu szczęśliwości, który jest tu rozważany jako cel ostateczny jest takie: Jeżeli osoba wierzy religijnie, że $p$ przynależy do credo jej religii, to jest do znanych twierdzeń tej religii - wówczas także wierzy, że jeśli nie wierzyłaby, że $p$, nie osiągnęłaby stanu szczęśliwości” (Weingartner 1994a, 126) ${ }^{8}$. Analizując różnice między przekonaniem religijnym i naukowym, autor zauważa, że teza (2.34) ma analogię w świecie przekonań naukowych (gdy wynalazca chce wierzyć w prawdziwość swojej hipotezy).

- Przekonania religijne zmierzają do dostarczenia „globalnej eksplikacji”, podczas gdy w przypadku przekonań naukowych nie podejmuje się prób dostarczenia takiej globalnej i ostatecznej eksplikacji zjawisk całego świata.

${ }^{8}$ Weingartner postuluje $\mathrm{w}$ tym miejscu swoistą logikę, uwzględniającą wolitywny charakter przekonań religijnych, wyrażający się tezą, że $G_{a}^{R} p \rightarrow W I L L_{a}\left[G_{a}^{R} p\right](2.34)$ (jeśli podmiot ma przekonania religijne, to chce je mieć). Do takiej tezy można dojść wychodząc z następujących przesłanek:

1. $G_{a}^{R} p \rightarrow B_{a}^{R}\left[\neg G_{a}^{R} p \rightarrow \neg H(a)\right]$ (gdzie $H(a)$ - ,a będzie szczęśliwy”)

2. $\operatorname{WILL}_{a}(H(a))$ (dowolny wierzący chce być szczęśliwy po tym życiu)

3. $\left[W I L L_{a} p \wedge B_{a}(p \Rightarrow q)\right] \rightarrow W I L L_{a} q$ : podwójna strzałka reprezentuje implikację spełniającą kryteria relewancji, mającą ustrzec tę formułę od generowania odpowiednika paradoksu Alfa Rossa (formułą niespełniającą kryterium relewancji jest np. prawo $p \rightarrow p \vee q$, generujące właśnie ów paradoks). (WEINGARTNER 1994a, s. 127). 
- Przekonania religijne odnoszą się do wiary w najwyższy i godny zaufania autorytet; dla przekonań naukowych zaś nie jest to istotne.

- Istotne dla przekonań religijnych np. chrześcijaństwie jest, że powinny się one manifestować w działalności religijnej; w wypadku przekonań naukowych nie można wskazać takich silnych powiązań ${ }^{9}$. Podstawowym argumentem przeciw takiemu rozumieniu przekonania religijnego (wiary) jest stwierdzenie Bocheńskiego (w dyskusji wokół tekstu Weingartnera zawartej w WEINGARTNER 1994), że Weingartnera charakterystyka przekonania religijnego dotyczy tego, co Bocheński zwie hipotezą religijną, a nie religii: „moja hipoteza religijna jest $\mathrm{z}$ tego samego poziomu, co hipoteza naukowa [...]. Ale wiara jest czymś absolutnie innym. Ma pewność absolutną; poza tym są jeszcze inne różnice. Jedna $\mathrm{z}$ nich — przekonanie naukowe jest relacją diadyczną pomiędzy osobą a sądem. $A$ wierzy, że $p$. Ale wiara $[\ldots]$ jest relacją ternarną. Istnieje wierzący, sąd, w który on wierzy oraz objawiający prorok. Istnieje relacja zaufania do założyciela religii, do proroka. [...] Dla Akwinaty przekonanie (wiara) jest w sposób całkiem jasny, relacją ternarną. I z moich rozmów z wierzącymi wynika, że głównym punktem ich wiary jest relacja zaufania do objawiającego autora, w naszej religii do Chrystusa" (Weingartner 1994, 140).

\section{DOGMAT PODSTAWOWY (HIPOTEZA RELIGIJNA)}

\section{A WIARA JAKO ZAUFANIE}

Zacytowana powyżej wypowiedź Bocheńskiego jest wyrazem zmiany poglądów w kwestii rozumienia przekonań religijnych. Podstawowe uwagi w tej sprawie Bocheński wyraził w Logice religii z 1965 r. (BocheŃsKI 1990). Stanowisko to po latach streścił w sposób następujący: „Założyłem [...] że akceptuje się przekonania religijne przez wiarę. Ten fakt może się komuś podobać lub nie, ale nie może być zanegowany. Idąc tym tropem, założyłem, iż akceptacja wiary wymaga, żeby użyć określenia Jamesa, „woli wiary", tj czynnika irracjonalnego. Stwierdziłem jednak, że żaden zdrowy umysłowo człowiek nie może zaakceptować jako prawdziwego zdania, które uznaje za ważne dla niego, bez ważnych powodów. Ale, jako że przekonania religijne są z pewnością takimi zdaniami, było zakładane, że istnieje pewne

\footnotetext{
${ }^{9}$ Ten moment, wyrażający się np. w wyznawaniu wiary, jest podstawowy dla życia osoby wierzącej w chrześcijaństwie (Rz 10,9), por też STh II-II, q. 3 O zewnętrznym akcie wiary.
} 
racjonalne uprawomocnienie dla akceptacji przekonań religijnych. W teologii katolickiej takie uprawomocnienie jest znane jako praeambula fidei" (BochEŃSKI 1994, 143). Najpierw zatem przypomnieć warto stanowisko Bocheńskiego z Logiki religii. Bocheński wskazuje tam, że dla zachowania zwanego religijnym charakterystyczny jest język, zwany dyskursem religijnym (DR), którego podklasą jest credo, a ,akceptacja credo jest tak ważna dla każdej religii, że wierny może być zdefiniowany jako osobnik, który zaakceptował wszystkie elementy odnośnego credo" (BochEŃsKi 1990, 15). Kluczową przy tym kwestią stawianą w Logice religii jest problem uzasadnienia na gruncie religii, innymi słowy czynności, na której mocy uzasadnia się akceptację zdania (znaczącego) ${ }^{10}$ (BocheŃski 1990, 91). Bocheński, podobnie jak gros polskich autorów, odróżnia uzasadnienie bezpośrednie, które składa się z aktu spostrzegania (zmysłowego lub niezmysłowego), w którym musi być obecny przedmiot spostrzegany oraz uzasadnienie pośrednie, uzyskane przez odniesienie do innych zdań, czyli drogą rozumowania (,przedmiot jest nieobecny”). Z drugiej strony Bocheński odróżnia uzasadnienie pośrednie w oparciu o zdania przedmiotowo-językowe od uzasadnienia metajęzykowego (gdzie do zdań przedmiotowych dołącza się przynajmniej jedno zdanie metajęzyka). W tym ostatnim przypadku najpierw ustala się (przez dedukcję, redukcję czy doświadczenie), że ilekroć zdanie $P$ przejawia pewną kontekstualną własność $\varphi$, tylekroć $P$ jest prawdziwe. Następnie zakłada się (na mocy dowodu lub doświadczenia), że $P$ ma własność $\varphi$ i wówczas wyprowadza się wniosek, że $P$ jest prawdziwe ${ }^{11}$. Takim rodzajem uzasadnienia jest np. uzasadnienie oparte na autorytecie. Według Bocheńskiego większość zdań dyskursu świeckiego również jest uzasadniana w oparciu o autorytet ${ }^{12}$. To ważna konstatacja, którą będzie można wykorzy-

${ }^{10}$ Jak zauważa Nicholas Wolterstorff, „gdy czytamy Akwinatę czy innych myślicieli średniowiecznych uderza nas fakt, że nie przykładają oni żadnej wagi do kwestii, czy wiara sama w sobie jest racjonalna. Kwestia odrębności wiary i rozumu po raz pierwszy staje się przedmiotem zainteresowań we wczesnym Oświeceniu" (WOLTERSTORFF 1988).

${ }^{11}$ Jako przykład takiego uzasadnienia Bocheński podaje, iż ,wierny zakłada, że elementy wiary obiektywnej są prawdziwe stosując regułę heurystyczną. Lecz reguła ta stwierdza, że kiedy zdanie wykazuje pewna własność kontekstualną (np. znajdujemy je w Pismach), to należy do powyższej klasy. W konsekwencji mamy do czynienia z uzasadnieniem metajęzykowym" (BoCHEŃSKI 1990, 93).

${ }^{12}$ Takie uzasadnienie oparte jest na dwóch przesłankach: 1) istnieją osoby, które są autorytetami w pewnej dziedzinie, oraz 2) jakieś zdanie zostało przez nie wypowiedziane i należy ono do danej dziedziny. Uzasadnienie pierwszej przesłanki „odbywa się na drodze dość osobliwego spostrzegania - spostrzeganie to dotyczy pewnych własności jednostki. Zazwyczaj spostrzeganie to zwiemy zaufaniem. Badając, co oznacza zaufanie, stwierdzamy, że jest to spostrzeganie dwóch zdań jako prawdziwych: 1) $A$ zna sytuacje w dziedzinie, w której jest autorytetem. 2) $A$ mówi prawdziwie 
stać również $\mathrm{w}$ kontekście $\mathrm{DR}$; jedną $\mathrm{z}$ dominujących koncepcji uzasadniania zdań DR jest koncepcja zaufania do źródła Objawienia, czyli Boga.

Bocheński przedstawia typologię różnych koncepcji uzasadniania w dyskursie religijnym, przy czym, co ważne, chodzi tu o uzasadnianie zdań bazowych dyskursu, jego podstawowych przesłanek, a nie zdań w ramach dyskursu religijnego (wewnątrz systemu) - te ostatnie, po przyjęciu dogmatu podstawowego (PD), uzasadnia się tak samo jak w ramach dyskursu świeckiego. Natomiast typologia koncepcji uzasadniania zdań bazowych dyskursu religijnego wymaga najpierw rozstrzygnięcia, czy PD jest w ogóle uzasadniany, a jeśli tak, to w jaki sposób. Stąd mamy następujący schemat ${ }^{13}$ :

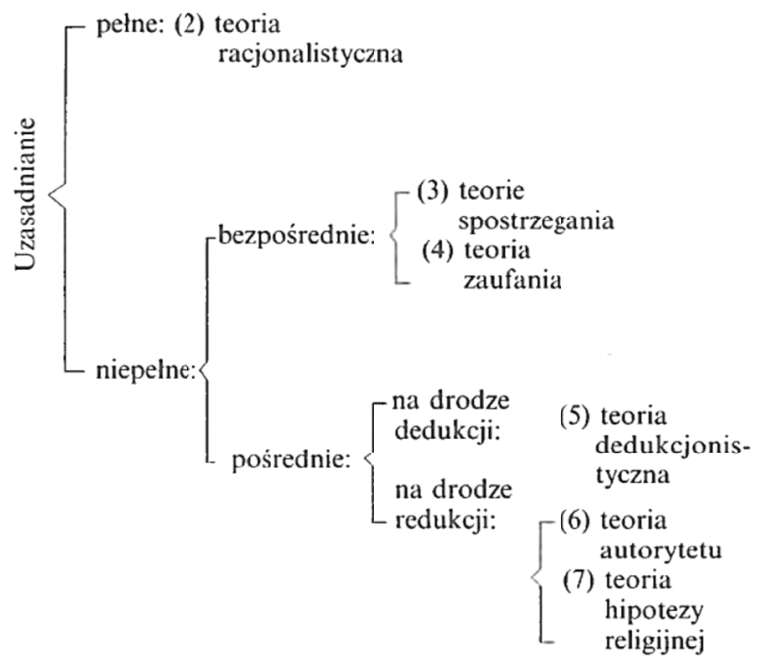

Ryc. za: BOCHEŃSKI 1990, 97.

W pierwszej spośród teorii, koncepcji skoku na oślep, PD nie jest poddany uzasadnianiu; dlatego nie ma tej koncepcji w naszym diagramie. Pozostałe koncepcje przyjmują możliwość takiego czy innego uzasadnienia PD. I tak koncepcja racjonalistyczna zakłada możliwość pełnego uzasadnienia w sposób naturalny $\mathrm{PD}$, wobec czego niepotrzebny jest krok wiary.

o elementach tej dziedziny do badanego. Stwierdzenie, że $S$ ufa $A$ w tym kontekście, oznacza dokładnie tyle: $S$ wierzy, że (1) i (2). Mogą i muszą wystąpić zjawiska uczuciowe towarzyszące akceptacji (1) i (2), lecz z logicznego punktu widzenia istotne jest wyłącznie to, że $S$ akceptuje (1) i (2)" (BOCHEŃSKI 1990, 95),

${ }^{13} \mathrm{Tu}$ tylko wspomnimy o tych koncepcjach, koncentrując się na Bocheńskiego koncepcji hipotezy religijnej. 
Następne zaś koncepcje dopuszczają jedynie częściowe uzasadnienie PD domagające się dopełnienia za pomocą aktu wiary. I tak teoria spostrzegania i teoria zaufania przyjmują, że takie uzasadnienie częściowe ma charakter bezpośredni; wierny ma wgląd częściowy w prawdy objawione albo też ma zaufanie do źródła Objawienia. Pozostałe zaś koncepcje przyjmują uzasadnienie pośrednie PD za pomocą dedukcji, której przesłanki są oparte na spostrzeganiu (koncepcja dedukcjonistyczna) lub odniesieniu do autorytetu (ludzkiego) jako źródła przesłanek (bez naszego wglądu w to źródło). Na koniec $w$ teorii hipotezy religijnej „wierny buduje, na podstawie znanych mu z doświadczenia przesłanek hipotezę wyjaśniającą. Hipoteza ta staje się PD po spełnieniu aktu wiary" (BocHEŃSKI 1990, 98).

Hipoteza religijna (HR) służy, według Bocheńskiego, wyjaśnianiu własnych przeżyć i, choć nie jest „psychologicznie tożsamą z wiarą, charakteryzuje się tą samą treścią, co akt wiary związany z PD" (BocheŃSKi 1990, 113). Procedura ustanawiania HR jest podobna do procedur stosowanych w naukach redukcyjnych. Punktem wyjścia są zdania uzyskane eksperymentalnie, które dają się z niej wyprowadzić. HR pozwala na przewidywanie, a może być zweryfikowana za pomocą nowych zdań eksperymentalnych z niej wydedukowanych.

Według Bocheńskiego można wskazać następujące podstawowe różnice między hipotezą religijną a zdaniami wyjaśniającymi w nauce:

a) baza zdań eksperymentalnych jest szersza niż baza w nauce: „w nauce mamy do czynienia wyłącznie z podklasą zdań eksperymentalnych uznawanych przez podmiot, hipoteza religijna wydaje się [...] oparta na wszystkich uznawanych przezeń zdaniach, na całości jego doświadczenia.

b) baza ta zawiera nie tylko zdania faktualne, ale także zdania estetyczne i moralne" (BOCHEŃSKI 1990, 113.).

Hipoteza religijna jest przyjmowana w ten sposób, że 1) podmiot uznaje, że jeśli uzna dogmat podstawowy religii, całość jego doświadczeń będzie można zorganizować i wyjaśnić, czyli, ujmując rzecz od strony logiki, HR pełni funkcję aksjomatu, z którego można wyprowadzić pozostałe przekonania podmiotu; 2) po sformułowaniu hipotezy, zostaje ona poddana weryfikacji w oparciu o inne zdania eksperymentalne uznawane przez podmiot.

Według Bocheńskiego natura tak określonej HR wyjaśnia dwie cechy DR:

a) trudności w przekonaniu innych do prawdziwości DR - wyjaśnienie tego faktu jest takie, że „dwie osoby nie mogą mieć tego samego całokształtu przeżyć, a w konsekwencji hipoteza, która jednej wyda się prawdopodobna, nie musi się wydać prawdopodobna drugiej, właśnie ze względu na związek z przeżyciami” (BochEŃsKI 1990, 114); 
b) solidność DR, czyli trudność jego falsyfikacji; wyjaśnieniem owej trudności jest wielka ogólność HR (,jest trywialną prawdą, że im ogólniejsze zdanie wyjaśniające, tym więcej zniesie prób falsyfikacji nie ulegając obaleniu").

Bocheński poddał analizie cztery odmiany wyjaśniania dostarczanego przez HR, a mianowicie:

1) HR wyjaśnia wyłącznie zdania faktualne. Ten sposób, według Bocheńskiego, nie ma miejsca w żadnej dojrzałej religii, gdyż wskazywałby na takie samo zachowanie HR jak każdej zwykłej hipotezy naukowej; np. choroba wyjaśniana jako kara za grzechy czy pomyślność gospodarcza jako nagroda za wierność;

2) HR koordynuje zdania o faktach ze zdaniami o wartościach. Wtedy HR ma charakter podobny do postulatu istnienia Boga $u$ Kanta, gdzie postulat istnienia Boga miał łączyć wartości z faktami. Według Bocheńskiego takie użycie HR jest dość powszechne, np. „HR pozwala na twierdzenie, iż istnieje życie pozagrobowe, w którym otrzymamy zadośćuczynienie za krzywdy, jakich doznaliśmy w życiu doczesnym";

3) HR wyjaśnia wyłącznie zdania o wartościach — bazą hipotezy byłby tu jedynie zbiór zdań o wartościach, podczas gdy zdania o faktach nie odgrywałyby żadnej roli; wtedy jednak PD musiałby być zdaniem o wartościach, a tak w żadnej religii nie jest. „Każdy znany nam dogmat podstawowy pozwala na wyciąganie przynajmniej pewnych konsekwencji faktualnych, na przykład, że Bóg istnieje";

4) HR wyjaśnia zdania o specyficznych przeżyciach religijnych; według tego poglądu istnieją specyficzne przeżycia religijne, które są wyjaśniane za pomocą $\mathrm{HR}^{14}$.

Wydaje się, że ostatni z rodzajów wyjaśnień dostarczanych przez HR nie prowadzi do trudności logicznych — pojawia się tu jednak kwestia istnienia specyficznego doświadczenia religijnego. „Pytanie dotyczy tylko tego, czy istnieją specyficznie religijne doświadczenia — a to jest problem empiryczny. Jeżeli da się wykazać w sposób przekonujący, że tak jest w istocie, to wystarczy już tylko pokazać, jaka jest struktura redukcji w odnośnych przypadkach" (BochEŃSKI 1990, 116).

${ }^{14}$ Wobec każdej z tych opcji można wysunąć zarzuty. Według 1) predykcje religijne nie różnią się od predykcji naukowych, według 2) klasa predykcji będzie pusta, według 3) można wysunąć jedynie predykcje o wartościach, przy czym rozumowania o wartościach nie mają struktury takiej, żeby można ją było analizować na gruncie logiki, a według 4) HR pozwala jedynie na nowe predykcje dotyczące przeżyć religijnych (BOCHEŃSKI 1990, 115-116). 
W Logice religii Bocheński dość sceptycznie odnosi się do możliwości stwierdzenia istnienia takiego specyficznego rodzaju doświadczenia. Jego poglądy ulegają zmianie w przywoływanym wyżej artykule Religious hypothesis revisited. Bocheński zauważa tu, że w stosunku do Logiki religii jego poglądy uległy zmianie w czterech kwestiach: pojęcia religii, doświadczenia religijnego, autorytetu oraz predykcji.

1) W Logice religii sprowadzano religię jedynie do systemu religijnego (zbioru zdań powiązanych logicznie). Bocheński odróżniał tam dogmaty danej wiary od meta-dogmatu, stwierdzającego, że dane credo jest prawdziwe, stojąc na stanowisku, że człowiek w trakcie konwersji nie zmienia swojego nastawienia do dogmatów danej religii, ale najpierw przyjmuje meta-dogmat (uznaje, że np. dogmaty chrześcijańskie są prawdziwe), a dopiero potem uznaje treść tych dogmatów (np. że Bóg istnieje). Tymczasem, jak podkreśla Bocheński (1994, 144), doświadczenie pokazuje, że najczęściej jest odwrotnie: „wielu nawracających się najpierw akceptuje istnienie Boga tj. dogmat, nie zaś meta-dogmat ich wiary". Te pierwsze tezy dotyczące przedmiotu religii Bocheński nazywa religią podstawową, odróżniając je od systemu religijnego, czyli credo ogłoszonego w „wielkich księgach religii”. W zmianie przekonań religijnych od bycia niereligijnym do bycia religijnym można zatem wyróżnić dwa kroki: akceptację religii bazowej (np. Bóg istnieje), potem zaś akceptacja meta-dogmatu danego systemu religijnego (czyli zdania głoszącego, że PD, credo, należy uznać za prawdziwe). Teoria HR miała zastosowanie do systemu religijnego, choć — zdaniem Bocheńskiego nie wiadomo, czy mogłaby się stosować do religii bazowej ${ }^{15}$.

2) Kwestia doświadczenia religijnego: w Logice religii Bocheński założył, że nie istnieje doświadczenie religijne. Jak wskazuje w Religious hypothesis, „było to powodem słabości tamtej teorii [...]. Teraz myślę, że jest konieczne dopuszczenie istnienia doświadczenia religijnego. Należy tu wprowadzić jednak podwójne rozróżnienie; najpierw powinno się rozróżnić właściwe doświadczenie religijne od religijnego wyjaśnienia doświadczenia świeckiego, a następnie [rozróżnić] spotkanie Transcendencji od spotkania sacrum w świecie", czyli

${ }^{15} \mathrm{~W}$ komentarzu do tekstu Bocheńskiego John Hick podkreślił wagę dla filozofii religii rozróżnienia religii bazowej i systemu religijnego: jeśli filozofia religii ma dotyczyć wielu religii, a nie tylko tej poszczególnej, trzeba przyjąć pojęcie religii bazowej, przez którą „rozumiemy to, co wszystkie te systemy religijne mają wspólnego i co w ogólności mówią wspólnego o Transcendencji czy Rzeczywistości” (WeINGARTNER 1994, 153). Bocheński w odpowiedzi udzielonej Hickowi zauważył jednak, że nie traktuje religii bazowej tak szeroko jak Hick i raczej skłania się ku stanowisku, że każda z wielkich religii ma swoją, różną od innych, religię bazową (WEINGARTNER 1994, 154). 


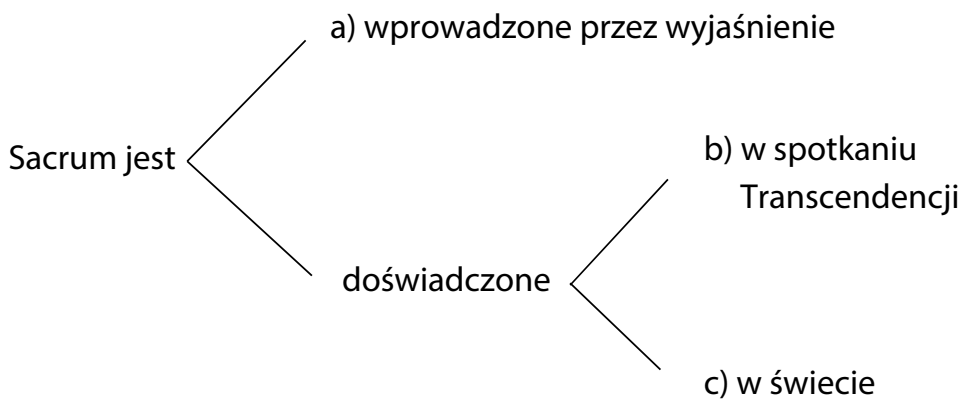

W Logice religii Bocheński dopuścił jedynie sacrum wprowadzone przez wyjaśnienie, odrzucając właściwe doświadczenie religijne. W Religious hypothesis revisited jest skłonny dopuścić c) i, z pewnymi zastrzeżeniami, także b). W kwestii spotkania Boga Bocheński zauważa, iż wielu pisarzy wskazuje, że istnieje specjalny rodzaj komunikacji z Bogiem i że wierzący doświadczają świętości w Nim. Choć większość wierzących nie ma takiego doświadczenia, to jednak np. mistycy o takim spotkaniu Boga mówią ${ }^{16}$. Wspomnijmy tu tylko, że w dzisiejszej literaturze kwestia racjonalności (a nie niemożliwości) doświadczenia religijnego jest żywo dyskutowana ${ }^{17}$.

William P. Alston w pracy Perceiving God dokonał analizy epistemologicznej doświadczeń religijnych mających charakter bezpośredniego poznania Boga (czyli podpadających pod stanowisko b) w typologii Bocheńskiego). Przykłady takich doświadczeń mają charakter percepcji niezmysłowej, której mogą towarzyszyć wrażenia zmysłowe lub „wrażenia duchowe", czyli specjalne jakości doświadczenia religijnego. Alston (nie rozstrzygając kwestii istnienia przedmiotu tych doświadczeń) wykazuje, że mogą one stanowić podstawę racjonalnych przekonań. W stanowisku Alstona, jak go streszczają Gutowski i Iwanicki, „główną racją na rzecz tej ostatniej tezy jest podobieństwo, pod odpowiednimi względami, doświadczeń religijnych do takich czynności poznawczych jak percepcja zmysłowa, introspekcja czy pamięć. Obrona racjonalności przekonań teistycznych ma w takim podejściu

\footnotetext{
${ }^{16}$ Choć, jak to zauważa Bocheński, używają terminu „spotkanie” w błędny i będący nadużyciem sposób.

${ }^{17}$ Być może ewolucja poglądów Bocheńskiego nastąpiła pod wpływem prac filozofów analitycznych, np. pracy Alvina Plantingi Reason and belief in God (PLANTINGa 1983); mniej więcej w tym samym czasie (1991 r.), co konferencja, której rezultatem jest WEINGARTNER 1994, ukazała się książka Williama P. Alstona Perceiving God (Alston 1993). Krótkie przedstawienie współczesnych dyskusji dotyczących doświadczenia religijnego można znaleźć w GUTOWSKI i IWANICKI 2016, 524-533.
} 
klarowną strukturę i polega na przyjęciu „domniemania niewinności” przekonań religijnych, a następnie uchylaniu zaproponowanych w trakcie dyskusji zarzutów czy racji unieważniających dla tych przekonań" (GUTOWSKI i IWANICKI 2016, 530). Struktura argumentacji Alstona może być przedstawiona w sposób następujący: Ponieważ (a) przekonania religijne oparte na doświadczeniu religijnym są racjonalne, o ile nie istnieją racje wystarczające dla ich unieważnienia oraz (b) nie istnieją racje wystarczające dla unieważnienia takich przekonań, a więc przekonania religijne są racjonalne. Przyjęcie zdania (a) zwanego zasadą zaufania w odniesieniu do przekonań religijnych odwraca sytuację w wypadku krytyki doświadczenia religijnego przenosząc ciężar argumentacji na krytyka doświadczenia religijnego musi on albo argumentować, że zasada zaufania nie stosuje się do doświadczeń religijnych (jako różnych od innych rodzajów poznania), albo też zgodzić się na zastosowanie tej zasady do doświadczeń religijnych, szukając odpowiednich racji unieważniających. Przy tym problemem dla argumentującego w ten sposób za doświadczeniem religijnym może być brak uniwersalności samego doświadczenia religijnego oraz różnorodność doświadczeń religijnych i zachodzące między nimi różnice.

Wracając do Bocheńskiego: przychyla się on do stanowiska c), czyli doświadczenia Boga w świecie. „W obliczu autorytetu badaczy studiujących religię jest konieczne dopuszczenie pewnego szczególnego doświadczenia religijnego rozumianego jako spotkanie świętości w świecie. To nie znaczy, że coś realnego, w szczególności Transcendencja, koresponduje z tym doświadczeniem. Nominalistyczne wyjaśnienie tego jest możliwe. Jeśli jednak wyjaśnienie realistyczne zostanie zaakceptowane, wówczas HR, pozostając wyjaśnieniem całokształtu ludzkiego doświadczenia jest pierwszą i nadrzędna hipotezą wyjaśniającą jego doświadczenie religijne” (BocHEŃSKI 1994, 147).

3) Następna korekta wprowadzona przez Bocheńskiego dotyczy jego poglądów na rolę autorytetu w uprawomocnieniu przekonań religijnych. W Logice religii stwierdzał, że żaden intelektualista nie może użyć autorytetu w uzasadnieniu przekonań religijnych. W analizowanym artykule Bocheński uważa tamtą tezę za niepoprawną. Odróżnia tu autorytet indywidualny (proroka, nauczyciela) od autorytetu wspólnoty i tezę o niemożności użycia autorytetu w uzasadnianiu przekonań religijnych, ,intelektualistów” zawęża do autorytetu wspólnoty. Uzasadniania może jednak dostarczyć autorytet świętych osób (nauczycieli czy proroków). Taka modyfikacja stanowi ograniczenie zasięgu działania teorii HR. Ostatnia z kwestii, w których poglądy Bocheńskiego uległy zmianie, to kwestia różnicy między HR a hipotezami 
naukowymi - te ostatnie dostarczają przewidywań, podczas gdy HR takich przewidywań nie dostarcza.

Podsumowując kwestie HR w świetle uwag Bocheńskiego zawartych w Weingartner 1994, należy zauważyć, że odszedł on znacznie od teorii HR. Podstawowe jest tu uznanie istnienia doświadczenia religijnego oraz, przede wszystkim, zmiana poglądu na naturę nawrócenia. Jeśli bowiem dopuszczamy możliwość jakiejś formy doświadczenia sacrum przez podmiot, to takie doświadczenie umożliwia zmianę jakiegoś przekonania na poziomie religii bazowej (dojścia do tezy o istnieniu Boga), w oparciu zaś o takie przekonanie podmiot może zmienić swój meta-dogmat, co doprowadzi go z kolei do przyjęcia credo (PD). Oczywiście można postawić pytanie o relację między zmianą przekonania na poziomie religii bazowej a zmianą meta-dogmatu; innymi słowy: dlaczego zmiana ta ma taki wpływ na meta-dogmat? To pytanie każe nam na nowo przyjrzeć się teorii zaufania analizowanej, i ostatecznie nieprzyjętej, w Logice religii. Warto tu przy okazji poczynić podstawowe rozróżnienie między uzasadnieniem przekonania religijnego a jego motywem. Zwraca na to uwagę Bocheński we wspominanej już dyskusji z Weingartnerem: „dogmat podstawowy głosi, że wszystko, co zawarte jest $\mathrm{w}$ credo danej religii, jest prawdziwe. Ale psychologiczna sytuacja wierzącego jest taka, że nie akceptuje on credo z powodu hipotezy religijnej, ale z powodu tego, że ufa Chrystusowi czy Mahometowi" (WeIngartner 1994, 140). Idąc tym tropem, wróćmy jeszcze na chwilę do koncepcji zaufania opisanej w Logice religii. Koncepcja ta zakłada, że PD jest uzasadniony bezpośrednio ze względu na zaufanie do objawiającego (Boga). Głoszący tę koncepcję odwołują się do sytuacji dziecka ufającego matce; „nie ma tu żadnego wnioskowania, tylko swoiste spostrzeganie osoby matki, w połączeniu z silnym uczuciem. [...] Naturalnie można powiedzieć, że występuje wówczas implicite pewna forma wnioskowania:

1) Dla wszystkich $P$, jeżeli $A$ powie $P$, to $P$ jest prawdziwe.

2) $A$ mówi $P$.

3) $P$ jest prawdziwe.

Obie przesłanki przyjęto jednak bez wnioskowania — pierwszą na mocy zaufania, drugą na drodze bezpośredniego doświadczenia" (BocHEŃsKi 1990, 104). Podstawowy jest punkt 1) i pytanie, jakie są warunki konieczne uznania tego punktu. Oczywiście, żeby można było ufać, $A$ musi istnieć. W wypadku matki, której dziecko ufa, jej istnienie jest dane bezpośrednio, natomiast $\mathrm{w}$ wypadku zaufania $\mathrm{w}$ kontekście religii można odróżnić sytuację, w której źródło objawienia okazało się wyłącznie prorokom (lub przez Pisma), 
i sytuację, w której źródło objawienia ukazuje się każdemu wiernemu ${ }^{18}$. Pierwsza z opcji według Bocheńskiego nie podpada pod teorię zaufania, jako że nie mamy danej bezpośredniej obecności objawiającego ani też bezpośredniości przekazu. Natomiast druga opcja nie prowadzi do trudności natury logicznej. Jest jedynie pytanie natury empirycznej co do tego, czy zachodzi stała i powszechna bezpośrednia komunikacja między źródłem objawienia a każdym wiernym. Bocheński w tej kwestii wypowiada swoją opinię dość ostrożnie: „osobiście autor jest przekonany, że teoria jest błędna z przyczyn natury empirycznej. Wydaje mu się bowiem, że brak takiego stałego objawienia masom wiernych, gdyż «żyją oni w mroku wiary», co znaczy, że całość dostępnego objawienia jest im przekazywana przez Pismo i wyznania wiary" (BochEŃSKI 1990, 106) ${ }^{19}$. Dopuszczenie bezpośredniego doświadczenia religijnego pozwala wyjść z „mroków wiary” przez jakiś rodzaj spotkania (poznania istnienia, obecności) Boga. Po takim spotkaniu wierny na zasadzie zaufania może zmienić radykalnie stosunek do Objawienia: treść Objawienia może być dana czy to przez Pismo, czy przez autorytet innych wierzących, „odczytanie” okoliczności, czy też w jakimś bezpośrednim kontakcie z Objawiającym (w chrześcijaństwie — natchnienie Ducha świętego ${ }^{20}$.

\section{Z POWROTEM DO TOMASZA: PRÓBA OKREŚLENIA WIARY I INNYCH POSTAW (AKTÓW?) RELIGIJNYCH}

Powyższe rozważania dotyczące przekonań religijnych, ich relacji do przekonań naukowych oraz problemu uzasadniania przekonań religijnych

18 „Źródło objawienia ukazuje się bezpośrednio każdemu wiernemu w taki sposób, że daje się spostrzec jego istnienie, a treść objawienia jest bezpośrednio zrozumiała dla każdego wiernego" (BOCHEŃSKI 1990, s. 105).

${ }^{19}$ Analizę pojęcia zaufania przeprowadza Linda Zagzebsky w Epistemic Authority (ZAGZEBSKY 2012, 122-128). Zagzebsky zauważa, że „gdy mówię do ciebie, że $p$, nie tylko stwierdzam, że $p$, ale także zamierzam to, że zaakceptujesz $p$, ponieważ powiedziałem tak. Proszę cię, żebyś zaufał mi, że przekażę ci prawdę. Kiedy wierzysz w to, co ci powiedziałem w ten sposób, akceptujesz moją prośbę i okazujesz mi zaufanie". Normalnie zaufanie jest podstawą komunikacji; jeśli informator jest wiarogodny i to, co mówi, nie pozostaje w sprzeczności z wiedzą informowanego, komunikacja przebiega ścieżką skróconą, tzn. nowa informacja jest „,wpuszczona” do systemu przekonaniowego odbiorcy.

${ }^{20}$ Zapewne moment doświadczenia jest ważny dla zmiany przekonań religijnych, jako uruchamiający proces zmiany (konwersję); wystarczy tu odwołać się np. do postaci św Pawła w drodze do Damaszku. Potem jednak, już po akceptacji bazowego przekonania, podmiot dokonuje (mówiąc językiem Bocheńskiego) zmiany meta-dogmatu, czyli decyzji o akceptacji credo i wtedy najczęściej żyjemy w „,ciemności wiary”, ufając w to, co dane jest w Piśmie (co też, zdaniem Bocheńskiego, głosił św. Paweł) (WEINGARTNER 1994, 158). 
możemy uzupełnić o garść uwag zaczerpniętych z traktatu św. Tomasza z Akwinu o wierze. Jest on trudny do analizy, gdyż choćby samo pojęcie wiary (religijnej) może mieć, według Tomasza, co najmniej trzy aspekty (sposoby rozumienia ze względu na przedmiot aktu). Tomasz wymienia mianowicie (STh II-II, 2.2 [s. 36]) wiarę Bogu, o której mówimy ze względu na zaufanie do Boga ${ }^{21}$, wiarę w Boga (gdzie Bóg jest materialnym przedmiotem wiary) ${ }^{22}$ oraz wiarę dla Boga (o której mówimy ze względu na cel ostateczny życia człowieka, którym jest przybliżenie się do Boga, „osiągnięcie” Boga).

Tomasz odróżnia wiedzę (przekonania) w sensie świeckim od wiary (przekonań religijnych). „Wiara (w sensie szerszym) jest wtedy, gdy rozum ma przekonanie o tym, w co wierzy" (STh II-II, 1, 4 [s. 15]). Mogą być dwa sposoby tworzenia przekonań. Z pierwszym sposobem mamy do czynienia, gdy „rozum jest prowadzony przez sam przedmiot”, który z kolei bądź jest zrozumiały sam w sobie (za pomocą intuicji) bądź jest zrozumiały przez dowód; mamy wtedy do czynienia $z$ wiedzą ${ }^{23}$. Drugi sposób jest wtedy, gdy „rozum wyrabia sobie przekonanie o czymś nie dlatego, że go do tego dostatecznie naprowadził własny przedmiot, lecz przez jakiś wybór woli, przechylający go na tę raczej, a nie inną stronę" (STh II-II, 1, 4 [s. 15]). Mogą tu być dwie możliwości: opinia, gdy towarzyszy jej „powątpiewanie i lęk przed ową inną stroną" albo wiara (nie towarzyszy jej lęk). Charakterystyczne dla wiary czy opinii jest to, że przedmiot jest niewidoczny (,jasne jest, że ani wiara, ani opinia nie dotyczą rzeczy widzialnych"; ibidem [s. 16] $)^{24}$.

„W wiedzy trzeba wyodrębnić dwoje: samo przekonanie (przechylenie, assensus) umysłu o rzeczy poznanej oraz badanie (consideratio) tejże rzeczy. Otóż przekonanie (assensus) wiedzy nie podlega wolnej woli, gdyż umysł jest zmuszony do przekonania siłą dowodu. Atoli badanie aktualne rzeczy poznanej podlega wolnej woli. [...] Jeśli chodzi o wiarę, to jedno i drugie podlega wolnej woli [...]. Przypuszczenie (opinia) zaś nie ma mocnego przekonania; według Filozofa jest ono kruche i słabe; dlatego, zdaje się,

${ }^{21}$ „Drugie, to swoisty sposób ujmowania przedmiotu, a jest nim ostateczny argument, dla którego daną prawdę przyjmujemy, i tu mamy akt wiary: wierzyć Bogu, bo [...] formalnym przedmiotem wiary jest prawda pierwsza; i właśnie w oparciu o nią człowiek nabiera przekonania do prawd wiary i przyjmuje je”; STh II-II, 2.2, s. 36 („wiara przeto opiera się o prawdomówność Boską jako motyw przekonujący" STh II-II, 1,1, s. 10)

${ }^{22}$ „Ze strony rozumu można dopatrzyć się w przedmiocie wiary dwojga: pierwsze, to materialny przedmiot wiary i tu mamy akt wiary: wierzyć w Boga"

${ }^{23}$ „Każda wiedza opiera się o jakieś zasady same z siebie oczywiste i w następstwie widome. Stąd trzeba przyjąć, że cokolwiek się wie, jakoś się i widzi” (s. 17)

${ }^{24}$ „Wiara jest dowodem tych rzeczywistości, których nie widzimy” (Hbr 11,1). 
nie pochodzi od woli stanowczej i stąd, ze strony przekonania, nie bardzo zdaje się mieć podstawę do zasługi” (STh II-II, 2, 9, ad 2 [s. 51]). W przypadku więc wiary mamy sytuację, że brak oczywistości (przedmiotowej) jest naprawiony (uzupełniony) przez wybór woli. „Wierzący nabywają ich [prawd wiary] znajomości nie drogą rozumowego dowodzenia, lecz pod wpływem światła wiary widzą konieczność uwierzenia w nie" (STh II-II, 1, 5, ad 1 [s. 18]) $)^{25}$.

Dyskusyjna dla Tomasza jest sprawa posiadania wiedzy i przekonań na ten sam temat u tej samej osoby. Może ona mieć wiarę i wiedzę o tym samym przedmiocie pod różnymi względami (np. mieć wiedzę o istnieniu Boga i jego jedności, ale wierzyć, że Bóg jest Trójcą). Nie można jednak mieć wiedzy, wiary i opinii na ten sam temat w tym samym aspekcie. Wiedza nie może iść w parze z opinią, bo „w pojęciu wiedzy zawiera się niemożliwość, by było inaczej" (co zwykle ma miejsce w opinii). Z kolei wiedza i wiara nie mogą iść w parze, gdyż wiedza implikuje widzenie (oczywistość), a wiara implikuje niewidzenie; w końcu wiarę od opinii różni brak pewności u tej ostatniej (ibidem) ${ }^{26}$.

Ważna jest relacja rozumu i woli w akcie wiary. „'Wierzyć' jest aktem rozumu pobudzonego przez wolę do uznania; a więc ten akt pochodzi i od woli, i od rozumu" (STh II-II, 4, 2 [s. 63]). Z kolei w odpowiedzi na zarzuty w kw. II, art. 9 Tomasz pisze, iż „'wierzyć' jest aktem rozumu, przekonanego o prawdzie Bożej z nakazu woli, ruszonej łaską przez Boga, i tak podlega wolnej woli skierowanej ku Bogu. A więc akt wiary może być za-

${ }^{25}$ Co ciekawe, Władysław Witwicki w Wierze oświeconych odwołuje się do tego fragmentu, wskazując, że „mamy tu bardzo współczesną analizę spostrzeżeń na przedstawienia i przekonania i mamy trafne stwierdzenie, że przekonania są od woli niezależne, wierzenia zaś religijne są od woli zależne i powinny być wywoływane przy współudziale woli, ażeby mogły być zasługą"; taki akt wywołany za pomocą woli Witwicki nazywa supozycją, albo też sądem nieszczerym (WITWICKI 1957, 98). Swoją drogą Witwicki tłumaczy assensus jako zgadzanie się wiedzy na rzecz, consideratio zaś jako przedstawienie rzeczy.

${ }^{26}$ Akt ,wierzyć” ma mocne przylgnięcie do jednej strony i w tym wierzący styka się z tym, który wie i rozumie; jego poznanie nie jest jednak tak doskonałe, by doszło do oczywistości widzenia, i w tym styka się z tym, który wątpi, podejrzewa i przypuszcza; a tak cechą właściwą wierzącego jest to, by, choć jest przekonany, dalej rozumował (właściwiej byłoby chyba „myślał” — cum assensu cogitet). Stąd ów akt „wierzyć” odróżnia się od wszystkich aktów rozumu, które dotyczą prawdy i fałszu" (STh II-II, 2, 1 [s. 35]). Rozważania tej kwestii Witwicki traktuje również jako poparcie swojej tezy, że Tomasz pojmuje akty wiary jako supozycje umyślnie wywołane, jako że zależą od woli (WITWICKI 1957, 98-103). Witwicki nie uwzględnia jednak jednego faktu, który u Tomasza jest zasadniczy, a mianowicie tego, że wola jest, według Tomasza, kierowana ku dobremu celowi i w tym sensie jest niezawodna (por. STh II-II, 4, 5 [s. 69]); problemu szczerości przekonań dotyka BROżEK 2019. 
sługujący." (ibidem [s. 51]). Moment łaski ma dla Tomasza zasadnicze znaczenie, jako że on gwarantuje doskonałość aktu wiary: „ponieważ wierzyć jest aktem rozumu, uznającego prawdę z nakazu woli, dwoje trzeba na to, aby ten akt był doskonały. Pierwsze, by rozum niezawodnie zmierzał do swego przedmiotu - prawdy; drugie, by wola niezawodnie kierowała się do celu ostatecznego, z powodu którego coś uznaje za prawdę" (STh II-II 4, 5 [s. 69]). Innymi słowy, wola (oświecona przez łaskę) jest tu gwarantem prawdziwości przekonania (wiary). Jej oświetlenie światłem łaski sprawia, że dzięki aktowi woli „naprawiony” jest niedostatek oczywistości spowodowany tym, że przedmiot materialny wiary ${ }^{27}$ jest niemożliwy (czy trudny) do bezpośredniego poznania.

Ciekawie w tym aspekcie wyglądają, analizowane przez Tomasza, niewiara, herezja i odstępstwo - ze względu na udział woli są one aktami (nie)zasługującymi. I tak, niewiara, to nie tylko brak przekonania, że $p$ (np. że Bóg istnieje), ale „przeciwieństwo wiary, gdy ktoś odmawia słuchania (prawd) wiary [...] i na tym polega istota niewiary; w takim ujęciu niewiara jest grzechem" (STh II-II, 10, 1 [s. 117]). Z kolei w wypadku herezji mamy do czynienia z wyborem, przy czym „wybór dotyczy środków do celu, który został uprzednio wytyczony. W przeżyciu wiary wola skłania się ku jakiejś prawdzie jako swemu dobru. Stąd wynika, że naczelna prawda pełni rolę ostatecznego celu [...]. Ponieważ zaś każdy kto wierzy, wierzy komuś mówiącemu, dlatego wydaje się, że punktem centralnym i ostatecznym w każdym uwierzeniu jest ta osoba, której wypowiedziom daje się wiarę, a gdy chętnie się komuś daje wiarę, to za drugorzędne uważa się to, w co się wierzy [...]. Kto ma prawdziwą wiarę chrześcijańską, ten z własnej woli wierzy Chrystusowi i przyjmuje to, co prawdziwie stanowi Jego naukę" (STh II-II, 11, 1 [s. 143]). Od tej prawdziwości można odejść w podwójny sposób: gdy ktoś nie chce wierzyć samemu Chrystusowi (zła wola); gdy ktoś chce wierzyć Chrystusowi, ale uchybia, przebierając w prawdach, które ma przyjąć ze względu na Chrystusa (gatunek niewiary), i to jest właściwie rozumiana herezja. W końcu odstępstwo jest odejściem od Boga i ma miejsce, gdy ktoś odstępuje od Boga, bo jego rozum stawia opór przykazaniom. Jeśli trwa w wierze, może pozostać w łączności z Bogiem, jeśli zaś utraci wiarę, całkowicie odstępuje od Boga; w takim sensie odstępstwo jest gatunkiem niewiary (STh II-II, 12,1 [s. 152]). Tak więc zarówno odstępstwo, jak i herezja są rodzajami niewiary, we wszystkich wypadkach spowodowanymi przez wybór.

\footnotetext{
${ }^{27}$ Warto tu przypomnieć, że Tomasz, zgodnie z zasadami scholastycznymi, odróżnia przedmiot materialny od przedmiotu formalnego wiary.
} 
Jak widać, całe Tomaszowe rozumienie wiary jako aktu, gdzie przedmiot nie jest dany w sposób wystarczający do posiadania odpowiednio mocnego przekonania (przez doświadczenie czy przez dowód oparty na przesłankach danych w doświadczeniu) i dlatego asercja musi być uzupełniona przez akt woli, wyraża postawę chrześcijańską, nazwaną wyżej, za Bocheńskim, ,życiem w ciemnościach wiary”. Akty woli są u Tomasza prowadzone światłem łaski. Działanie woli, ze względu na naturalne nakierowanie człowieka na zjednoczenie z Bogiem, podtrzymuje asercję (uzupełniając brak podstawy dla takiej pełnej asercji spowodowany niemożnością uzyskania pełnego poznania Boga). Jeśli się nie przyjmie jakiegoś „oświecenia woli”, trzeba dojść do konstatacji takiej, jak Witwicki, że wiara (opisana przez) Tomasza jest supozycją przemieniającą się w przekonanie nieszczere. Zapis formalny powyższych rozważań nie jest łatwy. Możemy tu naszkicować jedynie kilka prób definicji opartych na języku logiki klasycznej (teorii relacji). Współczesne systemy logik doksastycznych wydają się niezdolne do chwytania relacji trójczłonowych, a ich tezy są nader ubogie treściowo. Być może owocne by się okazały logiki kombinowane, w których występowałyby zarówno funktory doksastyczne, jak i funktory dotyczące chceń czy obowiązków. Na razie można, na koniec niniejszych szkicowych rozważań, podać następujące próby.

Myśl, że wiara jest relacją trójczłonową, można przedstawić za pomocą formuły: $W(x, y, p) \equiv[U(x, y) \wedge S(y, p) \rightarrow G(x, p)]$ (gdzie $U-$ ufa, $S$ - głosi), czyli ,x wierzy $y$, że $p$ ” to tyle, co ,jeśli $x$ ufa $y$, a $y$ głosi $p$, to $x$ jest przekonany $\mathrm{w}$ sensie mocnym, że $p$ ", przy czym „,x ufa $y$ " można opisać za pomocą wzoru:

$$
U(x, y) \equiv B(x,[B(y, p) \rightarrow p]) \wedge B(x,[S(y, p) \rightarrow B(y, p)]) .
$$

Inne określenie wiary może być wzorowane na definicji autorytetu podanej przez Bocheńskiego w postaci formuły:

$$
W(x, y, p) \equiv[A u(y, x, p) \wedge S(y, p) \rightarrow G(x, p)]^{28},
$$

${ }^{28}$ Gdzie autorytet jest charakteryzowany w sposób następujący: $(D$ - dziedzina, w której $x$ jest autorytetem dla $y): A u(x, y, D) \equiv \forall p(p \in D \wedge S(x, p) \rightarrow P(y, p))$.

Niektóre własności autorytetu:

$$
\begin{aligned}
& \neg(\exists x, D) A u(x, x, D), \neg(\forall x \forall y)\left(\left[A u\left(x, y, D_{1}\right) \wedge\left(D_{1} \neq D_{2}\right)\right] \rightarrow \neg\left(A u\left(y, x, D_{2}\right)\right)\right), \\
& (\forall x, y)(A u(x, y, D) \rightarrow \neg A u(y, x, D)) \\
& \text { czy w końcu }(\forall x, y, z)(A u(x, y, D) \wedge A u(y, z, D) \rightarrow A u(x, z, D)) \text { (BOCHEŃSKI 1993, 190). }
\end{aligned}
$$


czyli „, $x$ wierzy, że $p$ ” to tyle, co $W(x, p) \equiv \exists y W(x, y, p)$. Teraz trzeba by wprowadzić jeszcze funktor woli (chcenia), powiązać chcenie z działaniem czynnika nadprzyrodzonego itd. I jeszcze, dodatkowo, formuły te trzeba by zakorzenić w jakiejś ontologii formalnej wyższego stopnia (tak dobranej, by nie pozostała $\mathrm{w}$ konflikcie $\mathrm{z}$ tezami dotyczącymi wiary). Można też będzie próbować wykorzystać formalną ontologię przekonań Ontobella, uzupełniając ją o tezy dotyczące przekonań religijnych (GARBACZ i in. 2009).

\section{REFERENCJE}

Alston, William P. 1993. Perceiving God. Ithaca: Cornell University Press.

BocheŃSKI, Józef Maria. 1990. Logika religii. Warszawa: IW Pax.

BocHEŃSKI, J[ózef] M[aria]. 1993. Logika i filozofia. Warszawa: PWN.

BocheŃski, Józef Maria. 1994. Religious hypothesis revisited. W: Paul WeInGARTner (ed) Scientific and Religious Belief, (Philosophical Studies Series, 59), 143-160. Dordrecht: Kluwer Academic Publishers.

BROŻEK, Anna. 2019. „Wiara oświeconych. Uwagi metodologiczne o rozprawie Władysława Witwickiego oraz kilka przykładów stosunku «oświeconych» do Boga i wiary”. Roczniki Filozoficzne 67, nr 1: 35-63.

Garbacz, Paweł, Piotr Kulicki, Marek LeChNiaK, Robert Trypuz. 2009. „Do you still want to vote for your favorite politician? Ask Ontobella!". W: Formal Ontologies Meet Industry. (Proceedings of the 4th Workshop FOMI 2009, seria: Frontiers in Artificial Intelligence and Applications 198), red. Roberta Ferrario i Alessandro Oltramari, 102-113. Amsterdam: IOS Press, 2009.

GÄRDENFORS, Peter. 1988. Knowledge in flux: Modelling the dynamics of epistemic states. Cambridge: Bradford Book, The MIT Press.

GutowsKi, Piotr, i Marcin Iwanicki. 2016. "Doświadczenie religijne”. W: Jacek HoŁówKa i Bogdan DzIóBKowsKi. Panorama wspótczesnej filozofii, 503-540. Warszawa: PWN.

JADACKI, Jacek J. 2003. Aksjologia i semiotyka. Warszawa: Semper.

LECHNIAK, Marek. 2011. Przekonania i zmiana przekonań, Lublin: Wydawnictwo KUL.

LECHNIAK, Marek. 2018. „Twardowskiego teoria sądu jako źródło dociekań fillozofów polskich w ontologii przekonań". Filo-sofija 40 (20181), 1: 141-150.

LENZEN, Wolfgang. 1978. „Recent work in epistemic logic”. Acta Philosophica Fennica 30 (2): $5-219$.

Plantinga, Alvin. 1983. Reason and belief in God. W: Alvin Plantinga i Nicholas WolTERSTORFF. Faith and rationality. Notre Dame: University of Notre Dame Press.

Tomasz z Akwinu. 1966. Summa teologiczna. T. 15: Wiara, nadzieja. Przełożył Paweł Bełch. Londyn: Veritas.

Wolterstoff, Nicholas. 1988. Faith. W: The Routledge Encyclopedia of Philosophy. Vol. 3, red. Edward Craig, 538-544. London: Routledge.

Weingartner, Paul (red.). 1994. Scientific and Religious Belief, (Philosophical Studies Series, 59). Dordrecht: Kluwer Academic Publishers, 1994. 
Weingartner, Paul. 1994a. Similarities and differences between scientific and religious belief. W: Paul Weingartner (ed). Scientific and Religious Belief, (Philosophical Studies Series, 59), s. 105-142. Dordrecht: Kluwer Academic Publishers.

WOJTYSIAK, Jacek. 2014. „Zagzebski on models of revelation”. European Journal for Philosophy of Religion 6, nr 4: 77-89.

WOLEŃSKI, Jan. 2004. Granice niewiary. Kraków: Wydawnictwo Literackie.

WITWICKI, Władysław. 1957. Wiara oświeconych. Warszawa: PWN.

ZagZeBsKy, Linda. 2012. Epistemic Authority. Oxford: Oxford University Press.

\section{KILKA UWAG O LOGICE PRZEKONAŃ RELIGIJNYCH}

Streszczenie

Artykuł jest poświęcony analizie pojęcia przekonania religijnego przeprowadzonej w świetle logiki. Porównane zostanie pojęcie przekonania religijnego z pojęciem przekonania naukowego, następnie analiza Bocheńskiego koncepcji racjonalności przekonań religijnych (i ich uprawomocnienia) oraz ujęcia Tomasza z Akwinu pojęcia wiary w świetle logiki współczesnej.

\section{A FEW REMARKS ON THE LOGIC OF RELIGIOUS BELIEFS}

\section{Su m m ary}

An article is an introductory analysis of concept of religious belief in the language of logic. In its first part, there is a comparison of the concept of religious belief with the concept of scientific belief, next part is a presentation and analysis of Bocheński's conception of rationality of religious beliefs (and their justification), and the third part of article is an attempt of analysis of Aquinas conception of faith (in Sth II-II) in the light of contemporary logic.

Slowa kluczowe: logika religii; przekonanie religijne; wiara; uzasadnienie wiary; J.M. Bocheński; św. Tomasz z Akwinu.

Key words: logic of religion; religious belief; faith; justification of faith; J.M. Bocheński; St. Thomas of Aquinas.

Information about Author: Dr. hab. MAREK LeChNIAK, Prof. at KUL — the John Paul II Catholic University of Lublin, Faculty of Philosophy, Institute of Philosophy, Department of Logic; address for correspondence: Al. Racławickie 14, 20-950 Lublin; e-mail: marek.lechniak@, kul.pl; ORCID: https://orcid.org/0000-0002-0768-7963. 